\title{
Review of Robert B. Talisse's Overdoing Democracy: Why We Must Put Politics in its Place. New York, NY: Oxford University Press, 2019, ix + 198 pp.
}

\author{
ELIAS ANTTILA \\ Vrije Universiteit Amsterdam
}

The point of departure of Robert B. Talisse's Overdoing Democracy will feel familiar to even casual followers of American political news outlets or political online culture: since Donald Trump's election to the US presidency in 2016-and as evidenced by it-the American political spectrum has expanded further in both directions, which has resulted in increased animosity between political partisans. "Democratic politics", it is said, "is tearing us apart” (3). Talisse's book makes essentially two claims. First, it argues that, tragically, this is in fact the case: to their detriment, various kinds of political polarization have become a trend in Western democracies. Second, it provides a practical solution that involves forgoing political conversations and finding non-political activities to do together to heal the political divide. The book has three parts. The two parts of the book that each develop one of these arguments are prefaced with a separate background section, which provides new readers with some very basic democratic theory, making Overdoing Democracy accessible to a wider audience while still providing new academic insights.

The background section of the book (Part I: Framing the Thesis), which provides appropriate groundwork in democratic theory for the rest of the book, emphasizes accessibility. Readers completely new to democratic theory or political philosophy will find concrete, relatable examples in Talisse's discussion of the nature of democracy. In these examples and in their surrounding discussion, Talisse makes the conscious assumption that democracy is desirable and valuable on the whole, both as a form of government and as a principle of social life. Overdoing Democracy does not seek to persuade those inclined to distrust democracy on account of recent world politics or explain why democracy is a "capital social good" (12). Talisse briefly contrasts his support of democracy to anarchism, although in its brevity this contradistinction is misleading: in one sense, although anarchists all share an opposition to parliamentary politics on the grounds that they create hierarchy, viewing democracy as a principle of 
social life, as Talisse suggests, seems to match with contemporary leftanarchism very well. ${ }^{1}$

Anarchists aside, Talisse continues to frame his thesis with a discussion of the democratic views of Jane Addams and John Dewey. For Talisse, Addams and Dewey represent an overly trusting view of the power of democracy, which seeks to solve the social and political problems that arise in democracies by prescribing more democracy in public life. (At this point, it is not clear what practical interventions might follow from this prescription.) For Talisse, the main challenger to Addams' and Dewey's democratic philosophy is (not anarchists but) elitist-minded anti-democrats, who bracket the public as gullible masses to be managed, not empowered. These anti-democrats do not go by name in Talisse's text, but rather seem to be adherents to a kind of folk view. The conflict between Addamsian and Deweyan democrats and the elitist anti-democrats that Talisse puts forth could be understood as a version of the conflict between democrats and technocrats. Regardless, Talisse intends his own position to lie in-between these two views. Like the democrats, he places great value in democracy, and believes in both the intrinsic and instrumental value of democracy. However, unlike the democrats, he thinks that in the face of democratic hiccups such as polarization, in prescribing 'more democracy', democracy 'overdoes' itself, and consequently further polarizes the public to the detriment of good governance. Therefore, Talisse adds to his slogan 'democratic politics is tearing us apart' that it "must be put in its place" (11).

The rest of the book is devoted to arguing that democratic politics is in fact polarizing the electorate and that this is undesirable, and to explaining what can be done about it. In what follows, I recount the argument before raising some concerns. Part II of the book (Diagnosis) explicates and argues for this slogan in two parts. In saying that democratic politics is in fact 'tearing us apart', Talisse supports the claim that the political spectrum has become further polarized, and describes what that polarization is like. This argument is framed by introducing the concepts of political saturation and political reach. Political saturation (of social life) refers to the phenomenon where political projects come to dominate all or many aspects of social life. Political reach refers to the physical and social locations where the duties, obligations, and responsibilities of citizens are exercised. Using UK and US data, Talisse argues that political

\footnotetext{
${ }^{1}$ See, for example, Graeber (2010) for an accessible description.
} 
projects have come to overshadow all social encounters, which are becoming increasingly guided by the need to stay true to political 'allegiances'. For example, consumer-brand allegiances may also double as political allegiances, because consumers now view choosing and committing to brands to be politically charged. Talisse invites us to think about this kind of homogenization as a concentration of political allegiance within another allegiance (namely, consumer-brand allegiance). The same homogenization is also seen in physical spaces (a postal code can accurately predict the political beliefs of its inhabitants) and virtual spaces (social media and its users divide users into politically homogeneous social groups). Talisse ends this section by extending his argument to claim that the combination of this homogenization of spaces and the creation of relevance for political allegiances at every turn is, in fact, what drives the overextension of politics and belief polarization.

In order for polarization and the overextension of politics to be relevant, next, Talisse needs to argue that, all things considered, these phenomena are undesirable. To do this, Talisse first invokes a difference between political polarization and belief polarization. Political polarization indicates how divided political allegiances are, including the distance of party platforms (platform polarization); how absolute political allegiances are about their platform (partisan polarization); and how distrusting political opposites are of each other (affective polarization). Belief polarization, on the other hand, indicates the process by which people come to hold stronger versions of their views after discussing them with likeminded people. These two categories also seem to happily differentiate between polarization in cases where agents adopt more of a particular set of beliefs (political polarization) and cases of single-issue polarization. In discussing belief polarization, Talisse invites us to consider beliefs as affects that intensify as interlocutors become increasingly polarized. These political affects work primarily to affirm a group identity, which can then distort the views of those who do not belong in the group. Eventually, this causes members of the public to lose the ability to engage in rational discussion with others. Talisse speculates that the current political landscape even provides the right conditions for a civil war. This speculation aside, I note that Talisse's view of the dynamics of belief polarization is similar to that of Dan Kahan and his work on 'cultural cognition'.'

\footnotetext{
${ }^{2}$ See, for example, Kahan et al. (2012).
} 
Moving to the final part of the book, Talisse's last argument is prescriptive. Because Talisse observes that belief polarization is often conditional on inhabiting an environment that corroborates existing views, to put politics in its place, he suggests that heterogenous members of the public must find mutually engaging non-political activities to do together. Mutual non-political activities serve to both prevent polarization and depolarize those who already have become polarized, because they cultivate an attitude of 'civic friendship'. Civic friends respect each other as people who have equal say in shaping communities and society even if they may not personally like each other. This practice and the habit of civic friendship is intended to reel in the overextension of the saturation and reach of democratic politics, which is at the centre of political breakdown. And this, in turn, should fix the overreach of democracy. "Putting politics in its place” (31) means, unlike Addams' and Dewey's suggestion, prescribing less democracy, not more.

While Talisse's diagnosis is coherently argued, a few concerns shadow each of his arguments. First, while Talisse's claim that talking politics is rarely done in mixed company seems plausible, the empirical evidence provided with these three examples is somewhat inconclusive and incomplete. For example, the data Talisse provides does not accurately track the changes to how, where, and with whom political discussions occur over time, and just how much political brand allegiance is happening (and where and by whom). In the United States, for example, it is worth keeping in mind that most Americans who experience suffrage are still politically rather disengaged (when measured, for example, according to voter turnout, see DeSilver 2017) and do not like to talk about politics (Pew Research Centre 2019). It is true that polarization is taken to be an established reality in UK and US political settings, but a watertight conjunction or separation of conventional wisdom and the studied reality would require further evidence.

However, even granting the empirical premise of political polarization, Talisse's second argument also raises concerns: while it seems intuitive and plausible that polarization leads to a loss of abilities to engage with political opposites and that polarization is ultimately undesirable, these theses are ultimately a speculation. A countering speculation might claim, for example, that as political saturation and reach extend and as belief polarization occurs, the electorate discusses politics more and becomes more adept at reasoning against or together with our opponents; the more we argue, the better we get. In following the common narrative 
that polarization generally harms democracy, Talisse also does not discuss potential benefits that might arise from political conflicts, whose necessity and value are theorised and stressed, for example, by agonistic pluralists (see, for example, Wenman 2013). It is unclear why it is necessarily undesirable to form or hold extreme beliefs: radical ideals cannot be ruled out a priori as undesirable. In favouring agreement over disagreement and non-extreme beliefs over extreme beliefs, Talisse seems to unjustifiably favour centrism or the maintenance of a political status quo. (He strongly denies that his argument is centrist or conservative, but this insistence is not further justified.) Thus, it is difficult to accept uncritically the thesis that polarization is intrinsically undesirable.

However, even granting that political polarization is wholly undesirable, Talisse's prescriptive argument also faces difficult challenges. The prescription to find mutual non-political activities does not capture the imbalance of the stakes for each party in coming together. In many encounters, if not all, requesting neutrality is a non-neutral request. According to Talisse, some views are not to be tolerated, but it is not clear where this line is to be drawn, who gets to draw it, and why.

A second concern for his prescriptive argument, as Talisse himself points out, is that it is difficult to imagine what the apolitical activities could be. Voluntary work, games, entertainment, food, recreational activities, and talking about these seem to all be politically ripe, as Talisse notes. This concern is briefly taken up, explicating that it is hard work, but this note does not address the issue adequately. Talisse's argument here could be helped by considering how political some activities are, and especially in which ways they are political. The presumption here is that because an activity is political, it will polarise further or have disastrous consequences. This may often be the case; but in the cases that it is not, how did that happen?

A third challenge to the prescriptive argument could be made in terms of feasibility: how could Talisse's prescription be practically implemented? As the argument stands, Talisse seems to leave it up to the public to adopt his prescription, but why or how they could do that isn't clear. Along the lines of the second counter-argument, just how will people come together if they are already so polarized? More concretely, what might a policy intervention that takes on board Talisse's prescription look like?

To conclude, Talisse's book provides readers new to democratic theory, and political philosophy in general, an accessible entry point, one 
that is especially topical in the United States and some other Western democracies. Talisse's philosophical slogans are catchy, and they are sufficiently explained. This introduction chooses the familiar idea that political differences and differences in what we believe are becoming even farther apart from each other, and that this is to the detriment of a functioning democracy. This argument has some empirical merit, but its normative claim, which is universally against polarization, is not sufficiently justified. A concern about the argument's prescriptive component lies in its positing an (arguably false) equality between the costs of engaging in non-political activity. The theory also faces a cyclical difficulty: if political saturation and reach loom larger than ever, coming together over nonpolitical things seems improbable. Throughout his book, Talisse does insist that the task of overcoming polarization will not be easy, as evidenced by the problems raised here and in his chapters. However, while solutions to polarization may be difficult to uncover, so are its problematizations.

\section{REFERENCES}

DeSilver, Drew. 2017. "In Past Elections, U.S. Trailed Most Developed Countries in Voter Turnout.” Pew Research Center, May 15, 2017. https://www.pewresearch.org/facttank/2020/11/03/in-past-elections-u-s-trailed-most-developed-countries-in-voterturnout/.

Graeber, David. 2010. “Are You An Anarchist? The Answer May Surprise You!” The Anarchist Library, November 9, 2009. https://theanarchistlibrary.org/library/davidgraeber-are-you-an-anarchist-the-answer-may-surprise-you.

Kahan, Dan M., Ellen Peters, Maggie Wittlin, Paul Slovic, Lisa L. Ouellette, Donald Braman, and Gregory Mandel. 2012. "The Polarizing Impact of Science Literacy and Numeracy on Perceived Climate Change Risks." Nature Climate Change 2 (10): 732-735.

Pew Research Center. 2019. "Public Highly Critical of State of Political Discourse in the U.S." Pew Research Center, June 19, 2019. https://www.pewresearch.org/politics/2019/06/19/public-highly-critical-of-state-of-political-discourse-in-the-u-s/.

Wenman, Mark. 2013. Agonistic Democracy: Constituent Power in the Era of Globalization. Cambridge: Cambridge University Press.

Elias Anttila is a PhD candidate in philosophy at the Vrije Universiteit Amsterdam. They have interests in democratic theory and epistemic injustice.

Contact e-mail: <o.e.anttila@vu.nl> 